\title{
Effect of treatment with sunflower oil and in combination with pomegranate and plum sauce on the chemical, microbiological and sensory properties of marinated Carp fillets (Cyprinus carpio)
}

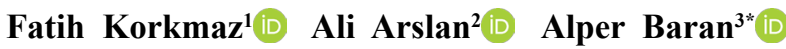

\author{
${ }^{1}$ Department of Aquaculture, Faculty of Fisheries, Atatürk University, Erzurum, Turkey. \\ ${ }^{2}$ Department of Food Hygiene and Technology, Firat University, Elazı $\breve{g}$, Turkey. \\ ${ }^{3}$ Department of Food Quality Control and Analysis, Erzurum Vocational School of Technical Sciences, Atatürk University, Erzurum, Turkey. \\ E-mail: alper.baran@atauni.edu.tr. "Corresponding author.
}

\begin{abstract}
The effect of sunflower oil (SO), sunflower oil-pomegranate sauce (PS1) and sunflower oil-plum sauce (PS2) on shelf life of marinated carp fillets was investigated in terms of sensory evaluation, chemical (peroxide value (POV), thiobarbituric acid (TBA), free fatty acids (FFA), total volatile basic nitrogen (TVB-N) and pH), and microbiological properties (Total viable count (TVC), Escherichia coli, Total coliform, Staphylococci/Micrococci, Salmonella spp.) during 30 days of storage. Proximate composition, which includes total crude protein\%,

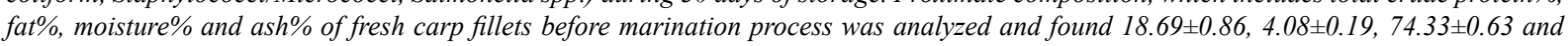
$2.17 \pm 0.45$, respectively. Sensory evaluation analysis showed that total appearance, odor-taste and texture scores decreased during storage. $T V B-N$ significantly increased in all group after 1 month of storage $(P<0.05)$. At the end of storage, the lowest TBA value $(1.38$ mg MA/kg carp fillet) was determined in the PS1 group. During storage, the highest POV value was observed in the control group (8.49 $\mathrm{mEq} \mathrm{O}_{2} / \mathrm{kg}$ ) compared to other groups. Initial TVC of $1.5 \log C F U / g, 1.7 \log C F U / g$ and $1.8 \log C F U / g$ increased to $3.7 \log C F U / g, 2.9 \mathrm{log} C F U / g$ and 3.2 $\log C F U / g$ in SO, PS1 and PS2 groups, respectively. Results showed that the shelf life of marinated carp fillets treated with sunflower oil and in combination with pomegranate and plum sauce was more than 1 month.

Key words: carp fillet, pomegranate, plum, shelf life.
\end{abstract}

Efeito do tratamento com óleo de girassol e em combinação com molho de romã e ameixa nas propiedades químicas, microbiológicas e sensoriais de filetes

de carpa marinados (Cyprinus carpio)

RESUMO: O efeito do óleo de girassol (SO), molho de óleo de girassol-romã (PS1) e molho de óleo de girassol-ameixa (PS2) na vida útil de filetes de carpa marinados foi investigado em termos sensorial, químico (valor de peróxido (PV), ácido tiobarbitúrico) (TBA), ácidos graxos livres (AGL), nitrogênio básico volátil total (TVB-N) e pH) e propriedades microbiológicas (contagem viável total (TVC), Escherichia coli, coliforme total, estafilococos/Micrococos, Salmonella spp.). Durante 30 dias de armazenamento. A composição aproximada, que inclui \% de proteína bruta total, \% de gordura, \% de umidade e \% de cinzas de filés de carpa frescos antes do processo de marinação foi analisada e encontrada 18,69 $\pm 0,86,4,08 \pm 0,19,74,33 \pm 0,63$ e 2,17 $\pm 0,45$, respectivamente. A análise sensorial mostrou que os escores totais de aparência, odor e sabor diminuíram durante o armazenamento. TVB-N aumentou significativamente $(P<0,05)$ em todos os grupos após 1 mês de armazenamento. No final do armazenamento, o menor valor de TBA (1,38 mg MA / $\mathrm{kg}$ de filé de carpa) foi determinado no grupo PS1. Durante o armazenamento, o maior valor de POV foi observado no grupo controle $\left(8,49 \mathrm{mEq} O \mathrm{O}_{2} / \mathrm{kg}\right)$ em comparação com outros grupos. $O$ TVC inicial de 1,5 log CFU/g, 1,7 log UFC/g, 1,8 log CFU/g aumentou para 3, $7 \log C F U / g, 2,9 \log C F U / g$, 3,2 log CFU/g nos grupos SO, PS1 e PS2, respectivamente. Os resultados mostraram que a vida útil dos filés de carpa marinados tratados com óleo de girassol e em combinação com molho de romã e ameixa era superior a um mês.

Palavras-chave: filé de carpa, romã ameixa, prazo de validade.

\section{INTRODUCTION}

Common carp (Cyprinus carpio L.) belongs to the Cyprinidae, the largest family of freshwater teleosts (VILIZZI, 2018). As a foodfish, carp is very popular around the world and in 2016, global culture of carp production reached 4.6 million tones (FAO, 2018). Marinades or marinated fish terms express to define fish products that comprise fresh, frozen, or salted fish or portions of fish processed by treatment with an organic acid, salt that is put into sauces, oil, or brines. Generally, marinated fish is consumed as a ready-to-eat product with no need to heat or cook (TKÁČOVÁ et al., 2020). Marinated fish is prepared and proffered with various vegetable oils or sauces considering the preferences of consumers. Recently, sauces such as pomegranate and tomato have been used in some studies for fish marination; 
although, these sauces are limited in sauce marinated products (KAYA \& BAŞTÜRK, 2018; KOCATEPE et al., 2019). In recent decades, due to the beneficial potential of various compounds in pomegranate, consumption of pomegranate fruit and products (sauce and dressing) has extremely increased (KALTSA et al., 2018). Pomegranate plant is rich in polyphenols, which play an important role in decreasing the risk of cardio and cerebrovascular diseases and eliminating cancer. They also show various biological activities such as inhibiting oxidation and microbial growth (VUČIĆ et al., 2019).

Due to high content of polyunsaturated fatty acids (PUFA), basically linoleic acid (18:2), constituting $68-72 \%$ of total fatty acid content, Sunflower Oil (SO) is considered as nutritious. Like in other vegetable oils, high PUFA in SO which is more susceptible to oxidative degradation prompts to rancidity, off-flavors and discoloration (PATTNAIK \& MISHRA, 2020). In the literature, SO has been used by some researches on the marination of products (KOCATEPE et al., 2019; GOKOGLU \& UCAK, 2020).

Plum varieties are grown either as a fresh fruit or for the production of dried commodities. A common review of the health effects of it includes antioxidant capacity of plums within the body (HERNÁNDEZ-RUIZ et al., 2018). The researchers have been investigated that the effect of pomegranate peel on the quality of marinated sardines (ESSID et al., 2020), influence olive oil and olive oil-pomegranate sauces on chemical, oxidative, and sensorial quality of marinated anchovy (TOPUZ et al., 2014), and the effects of encapsulated pomegranate peel extract on the chemical and microbial quality of silver carp (GANJIAN et al., 2020). Plum sauce has not been used before in marinating processes related to seafood. Whereas plum sauce with many acids is organic and having a positive impact on human health like pomegranate sauce (PS). Although, it was reported in these studies that PS and plum sauce had a good antioxidative effect, it was stated that their effects were limited due to merging and stability problems. In addition, carp is commonly consumed as fresh whereas marinated carp is not very popular.

This study aimed to investigate the sensory properties, chemical quality, microbiological parameters, proximate composition and shelf life of marinated carp fillets treated with SO, PS and plum sauces during storage at $4 \pm 1{ }^{\circ} \mathrm{C}$ for 1 month.

\section{MATERIALS AND METHODS}

\section{Materials}

Fresh common carp (Cyprinus carpio L.) was purchased from a fish market in Tunceli, Turkey.
Carp was transferred to the faculty of Aquaculture in Cukurova University to the Processing Laboratory with crushed ice in polystyrene boxes after quick freezing. The fillets were obtained from fish manually and they were washed with tap water in this laboratory. The mean weight and mean length of fillets were measured $382.68 \pm 16.52 \mathrm{~g}$ and $34.2 \pm 5.4$ $\mathrm{cm}$, respectively. Eight fillet parts were cut into small pieces each of which were around $5 \mathrm{~g}$. Acetic acid and $\mathrm{NaCl}$ were purchased from Merck Chemicals Co. SO (Ona Trade Adana-Turkey), PS and plum sauces were purchased from a local market in Adana-Turkey.

\section{Marinating 'process}

Marination process was conducted with a slight modification by the method reported by TOPUZ et al. (2014). Monotype marinating solution was prepared on the processing day, $3 \%$ acetic acid solution $(30 \mathrm{~mL} / \mathrm{L})$ was used. The salt content $(50$ $\mathrm{g} / \mathrm{L}$ ) was applied for marination solution. Fifty grams $\mathrm{NaCl}$ was dissolved in $500 \mathrm{~mL}$ of tap water and 30 $\mathrm{mL}$ of acetic acid was added to $1 \mathrm{~L}$ of tap water for dilution. five liters of total marinade solution was prepared consisting of $250 \mathrm{~g} \mathrm{NaCl}, 150 \mathrm{~mL} / \mathrm{L}$ acetic acid and $5 \mathrm{~L}$ tap water to put all pieces of carp fillets inside the big glass box. After forming marinade solution, all fresh piece of carp fillets was put into $5 \mathrm{~L}$ glass box for 1 week for marination.

\section{Storage conditions and the process of the fillets after marination}

Upon marinated at $4 \pm 1^{\circ} \mathrm{C}$ in the refrigerator in laboratory for 1 week, after maturated, the carp fillets were removed from the marinating glass and left to drain on a plastic wire mesh for $10 \mathrm{~min}$. Before adding SO, Sunflower oil-Pomegranate sauce (PS1) and Sunflower oil-Plum sauce (PS2) to the marinated carp fillets, the selected ratio of SO, PS1 and PS2 to marinated carp fillets was 1:3 (v:w) for suitable concentration in terms of taste (TOPUZ et al., 2014). After that, marinated carp fillets were divided into three groups. To put these fillets to glass, totally nine glass bottles (in the same volume $500 \mathrm{ml}$ ) were selected for each group to be treatment three. First group (SO) was put into three glasses without sauce containing only sunflower oil, (oiled-with sunflower oil-500 ml). Second (PS1) and third (PS2) groups were also put into three glasses containing SO-PS, (Oiled-Sauced-1: 3 (v:v) total volume $500 \mathrm{ml}$ ) and SO-Plum sauce (OiledSauced-1: 3 (v:v) total volume $500 \mathrm{ml}$ ). All samples were stored at cold temperature $\left(4 \pm 1{ }^{\circ} \mathrm{C}\right)$ for 30 days.

Before the analysis, the sauces and oil were removed from carp fillets with paper towel. The 
process was formed at the ambient temperature $(21 \pm 2$ $\left.{ }^{\circ} \mathrm{C}\right)$. Proximate composition analyses were performed on raw carp fillets. Following the marination process, chemical, microbial and sensorial analyses were performed on days 0,15 and 30 during storage time.

\section{Sensory analysis}

Sensory analysis of oiled-sauced carp fillets (appearance, odor, flavor, and texture) was scored according to previous reported method with a slight modification (OZOGUL et al. (2010). To conduct sensory analysis, 3 boxes of oiled-sauced marinated carp fillets were randomly taken from each group. Each assessment was conducted by 10 trained panelists. The features of the sensory analysis of oiled-sauced carp fillets after marination process were shown in Table 1. A hedonic scale from 1 to 9 was used to evaluate oiled-sauced marinated carp fillets. On this scale 1-4 indicates 'bad or unacceptable', 5-6 indicates 'acceptable', 7- 8 indicates 'good quality' while 9 represents 'very good quality'.

\section{Proximate analysis}

The fresh carp fillets were analyzed in triplicate for proximate composition. For this purpose, total crude protein, fat, ash and moisture content were analyzed (AOAC (2010).

\section{Chemical analysis}

Peroxide value (POV) was evaluated and shown in milliequivalents of peroxide oxygen $(\mathrm{mEq}$ $\mathrm{O}_{2}$ )/ $\mathrm{kg}$ of fat in fillet (AOCS (1998). The thiobarbituric acid (TBA) value was determined according to the method of TARLADGIS et al. (1964) and the results showed that as TBA value, mg of malondialdehyde
$\left(\mathrm{mEq} \mathrm{O}_{2}\right) / \mathrm{kg}$ of flesh. Free fatty acid (FFA) analysis was evaluated according to the AOCS (1997) method and showed as \%of oleic acid. The total volatile basic nitrogen (TVB-N) value was evaluated according to the method of LUDORF and MEYER (1973) and shown as $\mathrm{mg}$ of TVB-N/100 $\mathrm{g}$ fillet. The $\mathrm{pH}$ values of marinated and oiled-sauced were determined by a $\mathrm{pH}$ meter (WTW 315i; WTW GmbH, Weilheim, Germany).

\section{Microbiological analysis}

Microbiological analyzes were performed on carp fillets marinated on day of 0,15 , and 30 (OZOGUL et al. (2010). $225 \mathrm{~mL}(0.1 \%)$ sterile peptone was added to $25 \mathrm{~g}$ of sample in filtered stomacher bags and homogenized at room temperature for $1 \mathrm{~min}$ using a masticator. Appropriate dilutions were made up from homogenized samples. After that, $0.1 \mathrm{~mL}$ of each dilution was spread onto surface of appropriate plates. The total viable count (TVC) were enumerated on Plate Count Agar (Merck 1.05463; Darmstadt, Germany) at $32^{\circ} \mathrm{C}$ for $48 \mathrm{~h}$; Escherichia coli on VRBL agar (VRBL, CM0968, Oxoid, Hampshire, UK) at 30 ${ }^{\circ} \mathrm{C}$ for $24 \mathrm{~h}$; total coliform bacteria on Violet Red Bile agar (VRBA, CM0107; Oxoid, Hampshire, England) at $30^{\circ} \mathrm{C}$ for $24 \mathrm{~h}$; Staphylococci/Micrococci count on Baird-Parker agar (CM0275, Oxoid) at $37^{\circ} \mathrm{C}$ for $24-$ 48 h; Salmonella spp. count on XLD agar (CM469, Oxoid) at $37^{\circ} \mathrm{C}$ for $24 \mathrm{~h}$.

\section{Statistical analysis}

Statistical analyses were performed by using SPSS 20.0 statistical software (SPSS, Inc., Chicago, IL, USA). Significant differences at $\mathrm{P}<0.05$ was determined by one-way ANOVA. All experiments were carried out in triplicate.

Table 1 - Features of sensory analysis of oiled-sauced carp fillets after marination process.

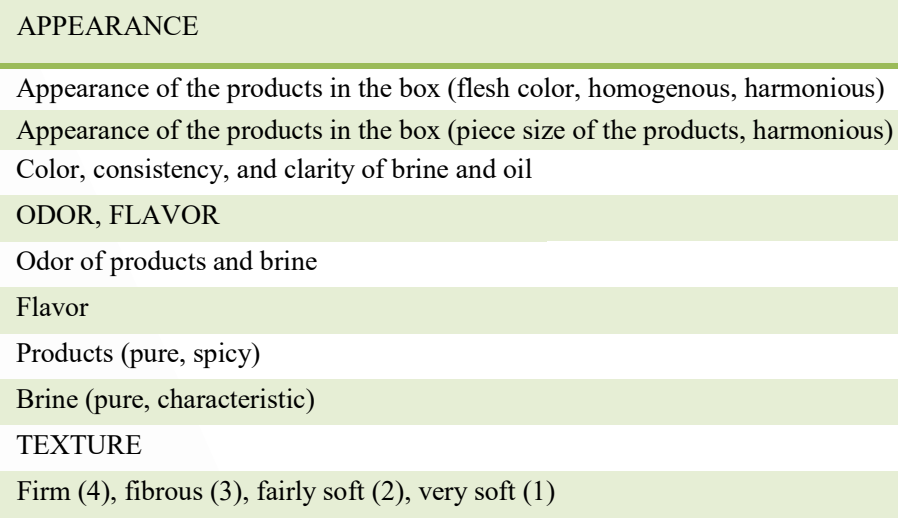




\section{RESULTS AND DISCUSSION}

Chemical properties of carp fillets are shown in the Table 2. The protein amount was higher than the previous studies (LINHARTOVÁ et al., 2018; MERDZHANOVA et al., 2018; SHEHATA et al., 2018) whereas the other study that was also reported in MOHAMMADI et al. (2018) was closely related to in this study result. The fat content was similar to that of reported by DJORDJEVIC et al. (2019). However, MERDZHANOVA et al. (2018), SHEHATA et al. (2018) and LINHARTOVÁ et al. (2018) reported that the lower fat values than the results of this study. The ash content of the carp fillets was different from the range reported by LINHARTOVÁ et al. (2018) and SHEHATA et al. (2018). The total moisture content of carp fillets was found $74.33 \%$. DJORDJEVIC et al. (2019) and SHEHATA et al. (2018) reported to similar data for the moisture composition of carp with $74 \%$ and $75 \%$, respectively. However, it was higher than the result reported by LINHARTOVÁ et al. (2018) and MOHAMMADI et al. (2018). The differences of all of these proximate compositions of carp fillets can be explained by geographical origin, reproductive status, season, diet and age (DONG et al., 2017).

Hydroperoxides are known as primary oxidation products. Hydroperoxides have degraded into ketones and the POV value between 5 and 10 $\mathrm{mEq} / \mathrm{kg}$ is considered the beginning of the rancidity (BOEREKAMP et al., 2019). In this study, the peroxide values of marinated carp fillets oiled-sauced with both SO, PS1 and PS2 are shown in Table 2. During the storage, the highest peroxide value among the groups was seen in control group $(8.49 \mathrm{mEq} \mathrm{O} /$ $\mathrm{kg}$ ). There was a significant increase of POV values in all samples after 30 days of storage $(\mathrm{P}<0.05)$. The results showed that samples treated with sauce PS1 and PS2 indicate a similar effect on decrease the production of peroxides in carp marinated fillets. When the antioxidative effect between marinated carp fillets was compared, it was reported that PS1 group was more effective than PS2 and SO $(8.10 \mathrm{mEq} \mathrm{O} /$ $\mathrm{kg}$ ) in hydroperoxide reduction. TOPUZ et al. (2016) reported a peak peroxide value of 18.23 and 16.45 $\mathrm{mEq} \mathrm{O}_{2} / \mathrm{kg}$, respectively, in the control and $25 \%$ olive oil-lemon juice emulsion groups of marinated anchovy fillets. In addition, they stated that in groups where 35 and $50 \%$ olive oil-lemon juice emulsion was applied, peroxide formation in anchovies marinated with almost twice lower peroxide values. The standard peroxide value is $3-25 \mathrm{mEq} \mathrm{O}_{2} / \mathrm{kg}$ sample according to the International Fishmeal and Oil Manufactures Association (IFOMA). Based on the available research data, it was observed that the peroxide values of carp fillets comply with the predetermined standard.

TBA is an important quality index that shows the oxidation of unsaturated fatty acids. Acceptable TBA consumption level is up to $8 \mathrm{mg}$ $\mathrm{MA} / \mathrm{Kg}$, while fish with a TBA value of $<3 \mathrm{mg} / \mathrm{kg}$ are evaluated as good quality (TESTA et al., 2019). The TBA values showed a significant increase after storage of 30 days in all samples after marinating process $(\mathrm{P}<0.05)$ (Table 3$)$. The lowest TBA value (1.38 mg MA $/ \mathrm{kg}$ carp fillets) was found for PS1 group at the end of the storage. This shows that the fish fillets remain of good quality even on the 30th day. The PS1 group gave the highest antioxidant activity, followed by PS2 and SO, while SO showed the lowest antioxidant activity during the storage of samples. Indeed, it has been reported in the past that seeds and fruits of pomegranate have antioxidant properties thanks to their high phenolic content (BCHIR et al., 2020; HASSANI MOGHADAM et al., 2020). Increase in TBA level during storage has been reported in several studies (TESTA et al., 2019; FICILAR \& GENCCELEP, 2020).

Oxidation products and FFA are known to have an effect on muscle tissue and function, because of the interaction with myofibrillary proteins is due to increased protein aggregation and also lipid oxidation. The appearance of free fatty acids (FFAs) is undesirable since the fatty acids may be transferred to odorous volatiles and are owing to the hydrolysis of lipids (CHAULA et al., 2019). In this study, FFA value between samples in all groups showed statistically no

Table 2 - Proximate composition of fish fillets.

\begin{tabular}{lc}
\hline Nutritional Value & Average (\%) \pm standard deviation \\
\hline Crude Protein & $18.69 \pm 0.86$ \\
Fat & $4.08 \pm 0.19$ \\
Ash & $2.17 \pm 0.45$ \\
Moisture & $74.33 \pm 0.63$ \\
\hline
\end{tabular}

Ciência Rural, v.51, n.4, 2021. 
Table 3 - Physicochemical properties of carp fillets during storage.

\begin{tabular}{|c|c|c|c|c|c|c|}
\hline $\begin{array}{l}\text { Storage } \\
\text { Time } \\
\text { (Days) }\end{array}$ & Group & $\mathrm{POV}(\mathrm{mEq} \mathrm{O} 2 / \mathrm{kg})$ & $\begin{array}{c}\text { TBA value } \\
(\mathrm{mg} \\
\text { malonaldehyde } / \mathrm{kg})\end{array}$ & $\begin{array}{c}\text { FFAs value } \\
\text { (Oleic acid \%) }\end{array}$ & $\begin{array}{c}\text { TVB-N } \\
(\mathrm{mg} / 100 \mathrm{~g})\end{array}$ & $\mathrm{pH}$ \\
\hline \multirow{3}{*}{0} & $\mathrm{SO}$ & $4.96 \pm 0.18 \mathrm{cB}$ & $0.27 \pm 0.14 \mathrm{cB}$ & $2.78 \pm 1.15 \mathrm{bB}$ & $9.07 \pm 0.48 \mathrm{cB}$ & 4. $27 \pm 0.04 \mathrm{aA}$ \\
\hline & PS1 & $4.96 \pm 0.16 \mathrm{cB}$ & $0.34 \pm 0.33 \mathrm{cA}$ & $2.87 \pm 1.16 \mathrm{bB}$ & $9.08 \pm 0.62 \mathrm{cA}$ & 4. $24 \pm 0.0 \mathrm{abB}$ \\
\hline & PS2 & $5.01 \pm 0.42 \mathrm{cA}$ & $0.26 \pm 0.20 \mathrm{bcC}$ & $2.83 \pm 1.30 \mathrm{bB}$ & $9.08 \pm 0.76 \mathrm{cA}$ & 4. $23 \pm 0.19 \mathrm{abC}$ \\
\hline \multirow{3}{*}{15} & SO & $7.54 \pm 0.96 \mathrm{abA}$ & $1.29 \pm 0.15 \mathrm{bA}$ & $3.95 \pm 0.58 \mathrm{aA}$ & $15.57 \pm 0.38 \mathrm{aA}$ & 4. $42 \pm 0.07 \mathrm{aA}$ \\
\hline & PS1 & $7.14 \pm 0.45 \mathrm{bC}$ & $1.03 \pm 0.23 \mathrm{bC}$ & $3.18 \pm 1.07 \mathrm{aA}$ & $13.96 \pm 0.61 \mathrm{aC}$ & $3.88 \pm 0.06 \mathrm{aC}$ \\
\hline & PS2 & $7.22 \pm 0.34 \mathrm{bcB}$ & $1.17 \pm 0.06 \mathrm{bB}$ & $3.31 \pm 0.78 \mathrm{aA}$ & $14.26 \pm 0.88 \mathrm{aB}$ & 4. $08 \pm 0.05 \mathrm{aB}$ \\
\hline \multirow{3}{*}{30} & $\mathrm{SO}$ & $8.49 \pm 0.42 \mathrm{aA}$ & $1.67 \pm 0.20 \mathrm{aA}$ & $5.99 \pm 0.49 \mathrm{aA}$ & $15.57 \pm 0.38 \mathrm{aA}$ & 4. $42 \pm 0.07 \mathrm{aA}$ \\
\hline & PS1 & $8.10 \pm 0.27 \mathrm{aC}$ & $1.38 \pm 0.24 \mathrm{aC}$ & $4.65 \pm 0.70 \mathrm{aA}$ & $13.96 \pm 0.61 \mathrm{aC}$ & $3.88 \pm 0.06 \mathrm{aC}$ \\
\hline & PS2 & $8.15 \pm 0.59 \mathrm{aB}$ & $1.55 \pm 0.35 \mathrm{aB}$ & $4.85 \pm 0.30 \mathrm{aA}$ & $14.26 \pm 0.88 \mathrm{aB}$ & 4. $08 \pm 0.05 \mathrm{aB}$ \\
\hline
\end{tabular}

${ }^{*}$ Each value is expressed as means \pm standard deviation $(\mathrm{n}: 3)(\mathrm{P}<0.05)$.

${ }^{* *}$ TVB-N, total volatile bases nitrogen; SO; control sample (Sunflower oil), PS1; sample sauced (Sunflower oil-Pomegranate sauce) and PS2; sample sauced (Sunflower oil-plum sauce).

Means within the same row (a, b, c, ) and the same column (A, B, C, ) with different letters are significantly different $(\mathrm{P}<0.05)$.

differences $(\mathrm{P}>0.05)$. As a matter of fact, ESSID et al. (2020) stated that during the storage of marinated sardine fillets of pomegranate juice and artichoke leaf, there was no change in the free fatty acid content including the control group; in all samples, conversely, free fatty acids values increased until the end of storage. FICILAR and GENCCELEP (2020) investigated the effects of sunflower oil as a filling material together with the sauce consisting of bay leaf and green tea extracts on marinated anchovies' fillets which they stored for 8 months. They reported that free fatty acids increased significantly in all groups, on the other hand, they reported a higher amount of free fatty acids in the control sample compared to the groups treated with plant extract during 8 months storage at $4{ }^{\circ} \mathrm{C}$. FFA value of samples in three groups increased on the 30 day of storage and then an important change showed during the storage $(\mathrm{P}<0.05)$. The highest FFA values were observed in the samples of sunflower oil at the end of the storage. This may be related to the inhibitory effect of phenolic compounds of pomegranate and plum on the release of free fatty acids.

TVB-N is identifying in general terms, which includes the measurement of volatile basic nitrogenous compounds, trimethylamine (TMA), dimethylamine (DMA) and ammonia associated with seafood spoilage (WELLS et al., 2019). TVB-N is used for assessing the level of fish spoilage and the changes occurring during the first of storage. TVB-N values were observed for all marinade samples. In this study, increases in TVB-N values were observed during storage in all samples significantly $(\mathrm{P}<0.05)$ (Table 4). The result can be thought to be due to microbiological and / or autolytic degradation of free amino acids and nucleotides and microbial reduction of TMAO to TMA (FICILAR \& GENCCELEP, 2020). Similarly, KOCATEPE et al. (2019) reported that the acid neutralizes the nitrogenous components in fish meat with the addition of brine, and as a result the $\mathrm{pH}$ values are more prone to acidity, while the development of TVB-N in all groups was reported to slow down during storage. However, they stated that no significant changes in the TVB-N values of the control group treated with rosemary and coriander essential oils were reported until the sixth month ( $P>0.05)$. TESTA et al. (2019) reported that the level of TVB-N of batch A (control) (consisting of anchovy fillets-marinade solution) and batch B (consisting of anchovy fillets-marinade solution with the olive leaf extract $(10 \mathrm{mg} / \mathrm{mL})$ was $<15.81 \mathrm{mg} / 100 \mathrm{~g}$ and 11.40 $\mathrm{mg} / 100 \mathrm{~g}$, respectively at the end of the marination process (22 days). In current study, PS1 and PS2 groups almost resulted in with similar decrease effects after 30 days. And also three groups were still below the maximum acceptable freshness limit of $35 \mathrm{mg}$ TVB-N/100 g fish fillet (LORENTZEN et al., 2020). Thus, this study result shows below the maximum permissible value of $25-35 \mathrm{mg} / 100 \mathrm{~g}$ set by the EU regulation (No 1022/2008) for different fish species. 
Table 4 - Total viable count in flesh of Oiled-Sauced Samples carp marinating fillets during storage periods.

\begin{tabular}{lcc}
\hline Storage Time (Days) & Groups & TVC (Total Viable Count) log CFU/g \\
\hline \multirow{2}{*}{0} & SO & $1.5 \pm 0.65 \mathrm{cC}$ \\
& PS1 & $1.7 \pm 0.70 \mathrm{cB}$ \\
15 & PS2 & $1.8 \pm 0.91 \mathrm{cA}$ \\
& SO & $2.5 \pm 0.53 \mathrm{bA}$ \\
30 & PS1 & $2.2 \pm 0.60 \mathrm{bC}$ \\
& PS2 & $2.4 \pm 0.85 \mathrm{bB}$ \\
\hline
\end{tabular}

${ }^{*}$ The average value \pm standard deviation; $\mathrm{n}: 3$ per experimental replicate.

${ }^{* *}$ Lower case letters $(\mathrm{a}, \mathrm{b}, \mathrm{c}$, ) and capital letters $(\mathrm{A}, \mathrm{B}, \mathrm{C}$, ) in means within the column represent the differences between days and groups, respectively $(\mathrm{P}<0.05)$.

There was also a parallel increase in TVB-N values in other marinated fish with this study (TOPUZ et al., 2016; SORIO \& INOLINO, 2018; ESSID et al., 2020; GOKOGLU \& UCAK, 2020).

In this study, at the end of the storage there were statistically significant decreases in $\mathrm{pH}$ values in the PS1 and PS2 groups compared to the control group $(\mathrm{P}<0.05)$. This decrease in $\mathrm{pH}$ values can be attributed to the hydrolysis of ATP in carp fillets to ADP and hydrogen ions and the dissolution of carbon dioxide. At the end of the storage period the lowest $\mathrm{pH}$ was obtained for samples marinated with pomegranate sauce $(\mathrm{P}<0.05)$. Similarly, it has been reported by ESSID et al. (2020) that there is no significant change in the $\mathrm{pH}$ values of marinated sardines with added pomegranate peel and artichoke leaf extract at the end of storage. The same authors stated that the $\mathrm{pH}$ value of marinated products should not be more than 4.8. In this study, the $\mathrm{pH}$ remained below 4.8 in all groups.

The most popular way of assessing the freshness of fish is sensory evaluation. This evaluation is simple, fast and provides immediate quality information. The sensory characteristics of fish must be clearly visible because of essential for consumer satisfaction (DILER \& GENI, 2018). Sensory attributes of marinated carp fillets are shown in table 5. Sensory scores of all samples significantly decreased $(\mathrm{P}<0.05)$ during the storage. Significant differences $(\mathrm{P}<0.05)$ on appearance, odor, taste and texture were determined in marinated sauce samples. Among the carp samples treated with SO, PS1 and PS2, the highest odor and taste scores were reported in the PS1 group. In contrast, the appearance and texture scores in the PS1 and PS2 groups were significantly lower than the SO group $(\mathrm{P}<0.05)$. Adding sun flower oil-pomegranate sauces to the carp marinade samples brought about darkening of the sample and with pomegranate and sauces, darker appearance was shown for PS1 and PS2, respectively. A significant decrease was observed in all groups on the appearance, odor, taste and texture scores during the storage period $(\mathrm{P}<0.05)$. Similarly, SZYMCZAK et al. (2020), TOPUZ et al. (2016) and GOKOGLU and UCAK (2020) reported the decrease in sensory scores when storage time is extended.

The maximum number of TVCs in all groups was below the acceptable upper limit of $10^{6}$ microorganisms/g (Table 4). Thus, the marinated carp fillets were found to have a microbial shelf life of over 30 days. In PS1 and PS2 samples TVC significantly decreased compared to PSO groups at the end of storage. This can be explained by the bacteria that can grow by adapting to the acid environment; although, they do not become completely ineffective following the marination process. At the same time, the results obtained in this study showed the antibacterial potential of pomegranate and plum. Several researches about marinated fish products show that the marination process done with several additives inhibited or decreased the number of microorganisms inside the fish (FICILAR et al., 2018; TESTA et al., 2019; ESSID et al., 2020). Also, E. coli, Salmonella spp, total coliform, and Staphylococci/Micrococci did not appear during 30 days of storage. The reason for this may be the fish going through a good handling 
Table 5 - Sensory attributes of carp fillets.

\begin{tabular}{lcccc}
\hline Storage Time (Days) & Groups & Appearance & Odour- Taste & Texture \\
\hline \multirow{3}{*}{0} & SO & $9.00 \pm 0.00 \mathrm{aA}$ & $8.15 \pm 0.63 \mathrm{bA}$ & $4.00 \pm 0.74 \mathrm{aB}$ \\
& PS1 & $8.37 \pm 0.88 \mathrm{bB}$ & $8.57 \pm 0.73 \mathrm{aA}$ & $3.33 \pm 0.71 \mathrm{bC}$ \\
\hline \multirow{3}{*}{15} & PS2 & $8.22 \pm 0.78 \mathrm{bC}$ & $8.37 \pm 0.61 \mathrm{bB}$ & $3.26 \pm 0.78 \mathrm{bA}$ \\
& SO & $8.78 \pm 0.60 \mathrm{aA}$ & $7.85 \pm 0.66 \mathrm{bA}$ & $3.34 \pm 0.81 \mathrm{aB}$ \\
& PS1 & $8.04 \pm 0.79 \mathrm{bB}$ & $8.40 \pm 0.75 \mathrm{bC}$ & $3.18 \pm 0.91 \mathrm{abC}$ \\
30 & PS2 & $7.89 \pm 0.93 \mathrm{bC}$ & $8.21 \pm 1.02 \mathrm{abB}$ & $3.12 \pm 0.77 \mathrm{bA}$ \\
& SO & $8.50 \pm 0.58 \mathrm{cA}$ & $7.16 \pm 0.98 \mathrm{bA}$ & $3.15 \pm 1.03 \mathrm{aA}$ \\
\hline \multirow{2}{*}{30} & $7.34 \pm 0.68 \mathrm{cB}$ & $8.10 \pm 0.49 \mathrm{cB}$ & $2.99 \pm 1.12 \mathrm{bB}$ \\
\hline
\end{tabular}

${ }^{*}$ The average value \pm standard deviation; $\mathrm{n}: 3$ per experimental replicate.

*** Means within the same row $(\mathrm{a}, \mathrm{b}, \mathrm{c}$, ) and the same column (A, B, C, ) with different letters are significantly different $(\mathrm{P}<0.05)$.

process in the facility, rapid freezing, transfer to the laboratory under suitable conditions and satisfactory hygiene measures while processing in the laboratory environment. However, the microorganism in food processing and storage conditions determines the type and amount of biogenic amine and toxic metabolites formed. Initial microorganism load, processing conditions, hygiene practices, processing procedures are the main factors that can affect the spoilage of marine fish products. This situation reflects the fact that the processing and storage conditions must be considered.

\section{CONCLUSION}

Recently, natural eatables are favored from consumers due to natural preservative and antioxidants such as, sunflower oil, pomegranate sauces and plum sauces. These sauces can be used as a natural antioxidant, preservative and flavoring additive in fish marinades such as carp marinades. In this study sunflower oil-pomegranate sauce and sunflower oil-plum sauce treatment (PS1 and PS2) have shown that these sauces enable to postpone chemical changes, inhibit lipid oxidation, maintain the sensory attributes, rich taste and extend the shelf life of the marinated carp fillets. Furthermore, use of sunflower oil showed also better organoleptic sauce properties an attractive xanthic color.

It is expected that extensive studies should be carried out to obtain better results in product quality and sensory properties, especially in the reduction of the black color caused by pomegranate and plum sauce, in sunflower oil-pomegranate sauce and sunflower oil-plum sauce. In addition, considering the storage conditions in marine fish products, it is clear that toxic metabolites that may occur due to possible microbial growth should be considered.

\section{ACKNOWLEDGEMENTS}

The research was conducted in the absence of any commercial or financial support.

\section{DECLARATION OF CONFLICTS OF INTERESTS}

The authors declare no conflict of interest. The founding sponsors had no role in the design of the study; in the collection, analyses, or interpretation of data; in the writing of the manuscript, and in the decision to publish the results.

\section{AUTHORS' CONTRIBUTIONS}

All authors contributed equally for the conception and writing of the manuscript. All authors critically revised the manuscript and approved of the final version.

\section{REFERENCES}

AOAC. Official methods of analysis of AOAC International. Gaithersburg (Maryland): AOAC International. 2010.

AOCS. Official Method Ca 5a-40. Free Fatty Acids in Crude and Refined Fats and Oils: AOCS Champaign. 1997.

AOCS. Official Method Cd 8-53. Peroxide Value-Acetic AcidChloroform Method: AOCS Champaign. 1998.

BCHIR, B., et al. Physico-Chemical, antioxidant activities, textural, and sensory properties of yoghurt fortified with different states and rates of pomegranate seeds (Punica granatum L.). Journal 
of Texture Studies, v.51, n.3, p.475-487. 2020. Available from: $<$ https://onlinelibrary.wiley.com/doi/abs/10.1111/jtxs.12500>. Accessed: Aug. 20, 2020. doi: 10.1111/jtxs. 12500.

BOEREKAMP, D. M. W., et al. Oxygen permeability and oxidative stability of fish oil-loaded electrosprayed capsules measured by Electron Spin Resonance: Effect of dextran and glucose syrup as main encapsulating materials. Food Chemistry, v.287, p.287-294. 2019. Available from: <http://www.sciencedirect.com/science/ article/pii/S0308814619304194>. Accessed: Aug. 21, 2020. doi: 10.1016/j.foodchem.2019.02.096.

CHAULA, D., et al. Fatty acid profiles and lipid oxidation status of sun dried, deep fried, and smoked sardine (Rastrineobola argentea) from Lake Victoria, Tanzania. Journal of Aquatic Food Product Technology, v.28, n.2, p.165-176. 2019. Available from: <https:// www.tandfonline.com/doi/full/10.1080/10498850.2019.1570992> . Accessed: Aug. 21, 2020. doi: 10.1080/10498850.2019.1570992.

DILER, A.; İ. Y. GENÇ. A practical quality index method (QIM) developed for aquacultured rainbow trout (Oncorhynchus mykiss). International Journal of Food Properties, v.21, n.1, p.858-867. 2018. Available from: <https://www.tandfonline.com/doi/full/10 .1080/10942912.2018.1466326>. Accessed: Jun. 10, 2020. doi: $10.1080 / 10942912.2018 .1466326$

DJORDJEVIC, V., et al. Effect of frying on the fatty acid composition of silver carp and common carp. Meat Technology, v.60, n.1, p.3036. 2019. Available from: <http://www.journalmeattechnology. com/index.php/meat technology/article/view/132/92>. Accessed: Aug. 20, 2020. doi: 10.18485/meattech.2019.60.1.5.

DONG, X.-P., et al. Physicochemical, micro-structural, and textural properties of different parts from farmed common carp (Cyprinus carpio). International Journal of Food Properties, v.20, n.4, p.946-955. 2017. Available from: <https://www.tandfonline.com/ doi/full/10.1080/10942912.2016.1190375>. Accessed: Aug. 23, 2020. doi: 10.1080/10942912.2016.1190375.

ESSID, I., et al. Use of pomegranate peel and artichoke leaf extracts to improve the quality of marinated sardine (Sardinella aurita) fillets. Journal of Food Science and Technology, v.57, n.2, p.713-722. 2020. Available from: $<$ https://link.springer.com/ article/10.1007/s13197-019-04104-x>. Accessed: Aug. 20, 2020. doi: 10.1007/s13197-019-04104-x.

FAO. Cultured Aquatic Species Information Programme Cyprinus carpio (Linnaeus, 1758). 2018.

FICILAR, B. B.; H. GENCCELEP. Influence of Garlic and Hot Pepper Sauce on the Quality of Marinated Anchovies during 7 Months at $4{ }^{\circ} \mathrm{C}$ Storage. Turkish Journal of Agriculture-Food Science and Technology, v.8, n.2, p.365-371. 2020. Available from: $<$ http://www. agrifoodscience.com/index.php/TURJAF/article/view/3055/1523>. Accessed: Aug. 22, 2020. doi: 10.24925/turjaf.v8i2.365-371.3055.

FICILAR, B. B., et al. Effects of bay leaf (Laurus nobilis) and green tea (Camellia sinensis) extracts on the physicochemical properties of the marinated anchovies with vacuum packaging. CyTA - Journal of Food, v.16, n.1, p.848-858. 2018. Available from: <https:// www.tandfonline.com/doi/full/10.1080/19476337.2018.1485747> . Accessed: Aug. 18, 2020. doi: 10.1080/19476337.2018.1485747.

GANJIAN, S., et al. Influence of encapsulated pomegranate peel extract on the chemical and microbial quality of silver carp (Hypophthalmichthys molitrix Val. 1844) fillet during refrigerating storage. Iranian Journal of Fisheries Sciences, v.19, n.2, p.9941005. 2020. Available from: <https://jifro.areeo.ac.ir/article_1207 06_209993536b39308c5fc3378f71c68b3c.pdf>. Accessed: Aug. 23, 2020. doi: 10.22092/ijfs.2019.118664.0.

GOKOGLU, N.; I. UCAK. Effect of freshness grade of anchovy (Engraulis encrasicolus) on the quality of marinated product stored at $4{ }^{\circ} \mathrm{C}$. Acta Aquatica: Aquatic Sciences Journal, v.7, n.2, p.54-59. 2020. Available from: $<$ https://ojs.unimal.ac.id/index. php/acta-aquatica/article/view/2459>. Accessed: Aug. 25, 2020. doi: http://doi.org/10.29103/aa.v7i2.2459.

HASSANI MOGHADAM, E., et al. Medicinal Properties of Pomegranate. 2020, v.4, n.3, p.127-139. 2020. Available from: $<$ http://hmj.lums.ac.ir/index.php/hmj/article/view/759>. Accessed: Aug. 19, 2020. doi: 10.22087/herb\%20med\%20j.v4i3.759.

HERNÁNDEZ-RUIZ, K. L., et al. Evaluation of antioxidant capacity, protective effect on human erythrocytes and phenolic compound identification in two varieties of plum fruit (Spondias spp.) by UPLC-MS. Molecules, v.23, n.12, p.3200. 2018. Available from: <https://www.mdpi.com/1420-3049/23/12/3200>. Accessed: Aug. 24, 2020. doi: 10.3390/molecules23123200.

KALTSA, O., et al. Stability, physical properties and acceptance of salad dressings containing saffron (Crocus sativus) or pomegranate juice powder as affected by high shear (HS) and ultrasonication (US) process. LWT, v.97, p.404-413. 2018. Available from: $<$ http://www.sciencedirect.com/science/article/pii/ S002364381830598X > . Accessed: Aug. 23, 2020. doi: 10.1016/j. lwt.2018.07.015.

KAYA, G. K.; Ö. BAȘTÜRK. Sensory and chemical qualities of marinated African catfish (Clarias gariepinus, B., 1822) preserved in oil and tomato sauce. Mediterranean Fisheries and Aquaculture Research, v.1, n.1, p.15-22. 2018. Available from: $\quad<$ https://dergipark.org.tr/tr/download/article-file/410653>. Accessed: Aug. 18, 2020.

KOCATEPE, D., et al. Influence of different essential oils on marinated anchovy (Engraulis encrasicolus L. 1758) during refrigerated storage. Food Science and Technology, v.39, p.255-260. 2019. Available from: <http://www.scielo.br/scielo. php pid $=$ S0101-20612019005001102\&script $=$ sci_arttext $>$. Accessed: Aug. 18, 2020. doi: 10.1590/fst.01318.

LINHARTOVÁ, Z., et al. Proximate and fatty acid composition of 13 important freshwater fish species in central Europe. Aquaculture International, v.26, n.2, p.695-711. 2018. Available from: <https://link.springer.com/article/10.1007/s10499-0180243-5>. Accessed: Aug. 19, 2020. doi: 10.1007/s10499-0180243-5.

LORENTZEN, G., et al. Temperature fluctuations in processing and distribution: Effect on the shelf life of fresh cod fillets (Gadus morhua L.). Food Control, v.112, p.107102. 2020. Available from: $\quad<$ https://www.sciencedirect.com/science/article/pii/ S0956713520300189>. Accessed: Aug. 19, 2020. doi: 10.1016/j. foodcont.2020.107102.

LUDORF, W.; V. MEYER. Fish and fish products. Berlin: Verlag Paul Parey. 1973. 308 p.

MERDZHANOVA, A., et al. Proximate composition, lipid quality and heavy metals content in the muscle of two carp species. Agricultural Science \& Technology (1313-8820), v.10, n.4, 
p.358-369. 2018. Available from: $<$ http://agriscitech.eu/proximatecomposition-lipid-quality-and-heavy-metals-content-in-themuscle-of-two-carp-species/>. Accessed: Aug. 17, 2020. doi: 10.15547/10.15547/ast.2018.04.066.

MOHAMMADI, M., et al. Effects of dietary supplementation of date palm (Phoenix dactylifera) seed extract on body composition, lipid peroxidation and tissue quality of common carp (Cyprinus carpio) juveniles based on the total volatile nitrogen test. Iranian Journal of Fisheries Sciences, v.17, n.2, p.394-402. 2018. Available from: <https://jifro.areeo.ac.ir/article 115477 e0de31fbe942ed3016a6be5e5d661924.pdf>. Accessed: Aug. 17, 2020. doi: $10.22092 /$ ijfs.2018.115477.

OZOGUL, Y., et al. The capability of rosemary extract in preventing oxidation of fish lipid. International journal of food science \& technology, v.45, n.8, p.1717-1723. 2010. Available from: <https://onlinelibrary.wiley.com/doi/abs/10.1111/j.13652621.2010.02326.x?casa_token=RIZ1 mUK40EMAAAAA:CTc d0T1mwjwIfiPkDten7Sr1rBVXqxpy3wp2_qXSaKOVa0ZRn_gdJjNC7v0xcFyMXmkA7R3s2CQ9Q>. Accessed: Jun. 17, 2020. doi: 10.1111/j.1365-2621.2010.02326.x.

PATTNAIK, M.; H. N. MISHRA. Effect of microwave treatment on preparation of stable PUFA enriched vegetable oil powder and its influence on quality parameters. Journal of Food Processing and Preservation, v.44, n.4, p.e14374. 2020. Available from: $<$ https://ifst.onlinelibrary.wiley.com/doi/abs/10.1111/jfpp.14374>. Accessed: aug. 18, 2020. doi: 10.1111/jfpp.14374.

SHEHATA, S., et al. Changes in the nutritional value of the smoked grass carp fillets during refrigerator storage. African Journal of Biological Sciences, v.14, n.1, p.109-120. 2018. Available from: <https://ajbs.journals.ekb.eg/article_65278 b41f21c68d96cbc5ad971ba1b1825964.pdf>. Accessed: aug. 19, 2020. doi: $10.21608 /$ ajbs.2018.65278.

SORIO, J. C.; R. I. INOLINO. Microbial, Chemical and Sensorial Quality of Chilled Marinated Green Mussel Perna Viridis,(Linnaeus, 1758). Current Research in Nutrition and Food Science Journal, v.6, n.1, p.135-141. 2018. Available from: $<\mathrm{http} / / /$ www.foodandnutritionjournal.org/volume6number1/ microbial-chemical-and-sensorial-quality-of-chilled-marinatedgreen-mussel-perna-viridis-linnaeus-1758/>. Accessed: Aug. 19, 2020. doi: 10.12944/CRNFSJ.6.1.15.

SZYMCZAK, M., et al. Effect of constant and fluctuating temperatures during frozen storage on quality of marinated fillets from Atlantic and Baltic herrings (Clupea harengus). LWT, v.133, p.109961. 2020. Available from: <http://www.sciencedirect.com/ science/article/pii/S0023643820309506>. Accessed: aug. 18, 2020. doi: 10.1016/j.1wt.2020.109961.

TARLADGIS, B. G., et al. Chemistry of the 2-thiobarbituric acid test for determination of oxidative rancidity in foods. II.- formation of the tba-malonaldehyde complex without acid-heat treatment. Journal of the Science of Food and Agriculture, v.15, n.9, p.602-607. 1964. Available from: <https://onlinelibrary.wiley. com/doi/abs/10.1002/jsfa.2740150904>. Accessed: May, 10, 2020. doi: $10.1002 /$ jsfa.2740150904.

TESTA, B., et al. Efficacy of olive leaf extract (Olea europaea L. cv Gentile di Larino) in marinated anchovies (Engraulis encrasicolus, L.) process. Heliyon, v.5, n.5, p.e01727. 2019. Available from: $<$ http://www.sciencedirect.com/science/article/pii/ S2405844019312824>. Accessed: Aug. 26, 2020. doi: 10.1016/j. heliyon.2019.e01727.

TKÁČOVÁ, J., et al. Sensory evaluation of fishery product-cod in mayonnaise. Journal of Microbiology, Biotechnology and Food Sciences, v.9, n.6, p.1084-1088. 2020. Available from: <https:// www.jmbfs.org/issue/february-march-2019-vol-8-no-4/jmbfs fbfs_533_tkacova/?issue_id=5293\&article_id=19>. Accessed: Aug. 20, 2020. doi: 10.15414/jmbfs.2019.8.4.1084-1088.

TOPUZ, O. K., et al. Quality Changes in Marinated Anchovy (Engraulis encrasicolus) Sauced with Olive Oil-Lemon Juice Emulsions. Journal of Aquatic Food Product Technology, v.25, n.6, p.905-915. 2016. Available from: <https://www.tandfonline. com/doi/full/10.1080/10498850.2014.968817>. Accessed: Aug. 19, 2020. doi: 10.1080/10498850.2014.968817.

TOPUZ, O. K., et al. Effects of olive oil and olive oil-pomegranate juice sauces on chemical, oxidative and sensorial quality of marinated anchovy. Food Chemistry, v.154, p.63-70. 2014. Available from: <https://www.sciencedirect.com/science/article/ pii/S0308814613019845? casa token=0rdZNoegUqUAAAAA:7 VN5YvBdx5si18c1R7mYuSWsDV0hwN1Jhh5WyiXMdEnsqD rS_6ttDbqdk0HU2xFtuteJnRdZ $>$. Accessed: Aug. 19, 2020. doi: 10.1016/j.foodchem.2013.12.103.

VILIZZI, L. Age determination in common carp Cyprinus carpio: history, relative utility of ageing structures, precision and accuracy. Reviews in Fish Biology and Fisheries, v.28, n.3, p.461-484. 2018. Available from: <https://link.springer.com/article/10.1007/ s11160-018-9514-5>. Accessed: Aug. 20, 2020. doi: 10.1007/ s11160-018-9514-5.

VUČIĆ, V., et al. Composition and potential health benefits of pomegranate: a review. Current pharmaceutical design, v.25, n.16, p.1817-1827. 2019. Available from: <https://www. eurekaselect.com/173320/article>. Accessed: Aug. 18, 2020. doi: $10.2174 / 1381612825666190708183941$

WELLS, N., et al. Colourimetric plastic film indicator for the detection of the volatile basic nitrogen compounds associated with fish spoilage. Talanta, v.194, p.830-836. 2019. Available from: $\quad<\mathrm{http}: / /$ www.sciencedirect.com/science/article/pii/ S0039914018311718>. Accessed: Aug. 18, 2020. doi: 10.1016/j. talanta.2018.11.020. 